\title{
DETERMINANTS OF FIRM DELISTING ON THE PRAGUE STOCK EXCHANGE
}

\author{
Zuzana Fungáčová, Jan Hanousek*
}

\begin{abstract}
:
This research investigates the emergence of stock market in the Czech Republic. We use Czech mass privatization as an experiment that allows us to analyze under what conditions a viable stock market arises. On the Prague Stock Exchange (PSE), unlike its counterparts in Poland or Hungary, exceptionally large amounts of shares were delisted e.g. excluded from public trading soon after trading at this market began in 1993. We estimate the determinants of shares delisting analyzing the period 1993-2004. Using firm-level data on listed and delisted companies we show that it was possible to prevent massive delisting if certain pre-privatization and privatization characteristics of the companies had been taken into account when deciding which companies to place on the stock exchange for public trading following the mass privatization. This result has important implications for establishing stock markets in emerging economies.
\end{abstract}

Keywords: stock market, delisting, privatization, transition economy

JEL classifications: G15, G28, P34

\section{Introduction}

Development of stock markets has differed across transition countries even though all of these markets had to be built from scratch after the collapse of central planning. In comparison to other structures of the economy, however, their development was less quick (Estrin et al., 2009). In general, two approaches to stock market creation

* Zuzana Fungáčová, Bank of Finland Institute for Economies in Transition (BOFIT), Snellmaninaukio, PO Box 160, FI-00101 Helsinki, Finland (zuzana.fungacova@bof.fi); Jan Hanousek, Charles University, CERGE-EI, Prague, Politických vězňů 7, 11121 Prague 1, Czech Republic; Anglo-American University, Prague; CEPR; WDI. (jan.hanousek@cerge-ei.cz).

For valuable comments and suggestions we are grateful to Sheraz Ahmed, Tom Berglund, Jarko Fidrmuc, Randall Filer, Iftekhar Hasan, Jan Kmenta, Iikka Korhonen and Jan Švejnar, participants of the BOFIT summer workshop in Helsinki (June 2006), the Czech Economic Society Conference in Prague (November 2006), the XVI International "Tor Vergata" Conference on Banking and Finance in Rome (December 2007), XXX Annual Meeting of the Finnish Economic Association in Jyväskylä (February 2008) and FMA European Conference in Prague (June 2008). While working on this paper, Fungáčová benefited from the GACR Grant No. 402/05/1014 and Hanousek benefited from the GACR Grant No. 402/09/1595. 
were recognized already at the beginning of transition. First, a standard, the so called top-down approach, characterized by gradual growth of market capitalization and the number of securities listed. A bottom-up approach, on the other hand, starts with a large number of listed shares out of which only some survive on the market (Simoneti, 1997). Thus, despite expectations of growth in the number of listed securities as well as the amount of trade, some stock markets in transition economies have, after the initial boom, experienced massive delisting, i.e. a large proportion of the listed share issues was excluded from public trading within a relatively short period of time. This massive delisting together with virtually no new listings points out problems in fulfilling the main functions of the stock market ${ }^{1}$ which, based on our conjecture, may have roots in the way these markets were established.

The phenomenon of delisting is to a certain extent a common occurrence in developed economies as well. Nonetheless, the number of delisted share issues is insignificant compared to the size of the market. ${ }^{2}$ Moreover, transition economies have in general lagged behind the developed ones in the number of new listings (Köke and Schröder, 2002; Bakker and Gross, 2004).

Delisting from the transition markets can be viewed from several different perspectives. Firstly, it indicates that in some cases unsuitable companies were initially placed on the market. Here delisting benefited the market because these companies left the market and thus it became more transparent. On the other hand, delisting in transition economies could hurt small investors with minority holdings ${ }^{3}$ because there were no exit rules defined at the time of delisting. Furthermore, massive delisting brought about negative sentiment at the market. Delisting in conjunction with practically no new listings contributed to the shrinking of the market, which then offered fewer investment opportunities.

This also applies to the Czech stock market, where the number of liquid securities traded on the stock exchange is relatively low. ${ }^{4}$ Despite high expectations, there were only a few initial public offerings and investors therefore invested their resources abroad. In this way Czech investors in fact indirectly financed the growth of foreign economies, while the growth of the Czech economy suffered ${ }^{5}$. Meanwhile, there was a growing trend in the number of listed securities since the beginning of trading on the Warsaw and Budapest Stock Exchanges which exhibited increases in market capitalization as shown in Egert and Kočenda (2007). These markets have also managed to attract companies from abroad. Thus, unlike the Czech stock market, they were able to channel capital to the corporate sector, especially through IPOs.

1 For example they did not fulfil their information function; see Hanousek and Filer (2000), who showed that prices were disconnected from reality. Unlike Poland and Hungary, the Czech stock prices did not correspond to economic values in the period 1993-1999.

2 According to the New York Stock Exchange (NYSE) Factbook (2003), 6\% of NYSE companies were delisted in 1997. In the same year, 75\% of companies were delisted from the Prague Stock Exchange (PSE). The proportion of companies delisted from the NYSE within a year has not exceeded 10\% in the period 1995-2002 (NYSE Factbook).

3 As was the case, for example, in Romania (Pop, 2006) or Bulgaria (Atanasov et al., 2010).

4 In fact, liquid securities are only those that belong to SPAD (System for Support of Share and Bond Market).

5 It is estimated that the Czech economy lost as much as $1.5 \%$ of its growth (Ekonom 3/2005). 
Taking into account institutional and other reforms, we conjecture that differences in the development of the Czech market, on one hand, and the Polish or Hungarian stock market, on the other, have been the result of policies applied in the early stages of the transition process; most importantly privatization which, based on Bonin and Wachtel (2003), laid the foundation for the development of stock markets. In Poland and Hungary the primary privatization method was direct sales, while in the Czech Republic it was mass privatization. This method, as our previous research suggests (Fungáčová and Hanousek, 2006), exhibited a negative short-run impact on the emerging stock markets in transition countries.

Czech mass privatization can therefore be regarded as an experiment which allows us to investigate under what conditions a viable stock market arises. In this paper we analyze this by employing firm-level data. Using data on listed and delisted companies we show that it was possible to prevent massive delisting if certain pre-privatization and privatization characteristics of companies had been taken into account when deciding which companies to place on the stock exchange for public trading following mass privatization.

The following section gives a description of stock market emergence and delisting process on the Prague Stock Exchange. In section 3 we discuss the specifications of the estimated models and the data used. Discussion of results and robustness checks follow in Section 4. Section 5 concludes.

\section{Stock Market Development in the Czech Republic}

Establishment of the Prague Stock Exchange (PSE) in the early 1990s and its further functioning was closely related to mass privatization. However, this privatization method did not fulfill the expectations of its proponents. It failed to concentrate companies' ownership structure, minority shareholders' rights were harmed, foreign investors were not attracted (Kočenda and Valachy, 2002), capital necessary for companies' restructuring was not generated (Lieberman, 1997), and state remained in control of already privatized companies for excessively long period (Hanousek and Kočenda, 2008). Moreover, it incurred certain hidden costs that concern the evolution of necessary market institutions of the type that function in the developed market economies. The stock market is undoubtedly one of them.

The stock market was formally set following the end of the first wave of mass privatization. Under this scheme shares of all privatized companies were legally required to be mandatory listed on the stock exchange ${ }^{6}$ (PSE Monthly Report, May 1997). Even though listing requirements for companies desiring to enter the market were formally defined by $1993,{ }^{7}$ privatized enterprises were not subject to them. This is not

6 Even though the listing was mandatory, not all privatized companies appeared on the stock exchange. In the first wave 988 companies were privatized, yet only 955 share issues were listed on the stock exchange. Even the stock exchange authorities cannot explain this difference. Following the second wave, 674 share issues were listed and three issues were not listed because of their limited transferability. Altogether 861 enterprises participated in the second privatization wave.

7 Listing requirements at that time concerned the volume of an issue earmarked for public offer (min. CZK 100 mil. i.e. USD 3.4 mil.), percentage of an issue realized through public offer ( $\min .20 \%$ of the total volume of an issue) and the length of the issuer's existence (min. 2 years). In fact, a lot of companies that were placed on the stock exchange after privatization did not satisfy these requirements. 
a standard approach towards stock market creation because privatization authorities, not companies themselves, were the ones to decide on listed companies. Although the managers of privatized companies prepared the privatization plans themselves and chose to participate in the voucher privatization program, ${ }^{8}$ later evidence from the stock exchange indicates that they did not know that this privatization method was connected to the mandatory listing of their shares. ${ }^{9}$ Moreover, at the time of submission of their privatization projects to the responsible ministries, virtually no legislation concerning the stock market and its functioning was in force. ${ }^{10}$

The above description suggests that the approach to market creation adopted in the Czech Republic was purely an administrative decision that ignored the usual listing requirements and suppressed the traditional concept of stock market development. Consequently, companies that under standard conditions would prefer to be privately owned ended up being public. The PSE started trading on April 6, 1993 and by June 22, 1993622 share issues from the first privatization wave were being traded there. Just a few weeks later the remaining share issues (333) from the first wave entered the market. The number of securities grew further after the second privatization wave and the highest number of security issues ever registered on the exchange (a total of 1,792) was achieved on May 2, 1996. Market capitalization to GDP reached 31.3\% in 1996, which was much higher than in any other transition economy. Similar figures at that time were $11.66 \%$ in Hungary, 6.42\% in Poland and 9.5\% in Russia (EBRD Transition Report, 1999). This number is comparable to the market capitalization figures in developed economies, but when adjusted for the size of the public sector and investment fund holdings, the actual market capitalization in 1997 was 13.7\% (Czech Republic: Capital Market Review, 1999), ${ }^{11}$ hence the new market was rather non-transparent. This was not only due to the large number of listed securities but also because most of the transactions were conducted off the main market (Hanousek and Podpiera, 2004). The price-setting central market on the PSE remained relatively insignificant and the prices did not carry true information. After foreign investors left

8 This was already envisaged before actual privatization started: "Most companies will join, either voluntarily or on the orders of the government, a give-away scheme based on investment vouchers" (The Economist, 1991). Moreover, Kotrba (1995) suggests that authorities "recommended" voucher privatization as the most suitable method.

9 PSE Monthly Report (May 1997) mentions that some issuers were surprised when they were told about their stocks being listed on the stock exchange. This is in line with a general view that many mass privatization programs were slow to recognize the natural link between privatization and development of a capital market (Lieberman, 1997).

10 Companies were obliged to submit their privatization projects by October 31, 1991 for the first privatization round and by July 16, 1992 for the second round. A commercial code was enacted on November 5, 1991 and a securities law on November 20, 1992. This indicates that even the policymakers were not fully aware of the connection between mass privatization and the stock exchange at the beginning.

11 State holdings were subtracted as they were not in fact traded. The value of investment funds holdings was also deducted because the value of their shares was added to the value of the securities in which they were invested, thus they were double counted. As the funds' own shares were valued at an average discount of about 40 percent relative to the portfolio value of the shares in which they were invested, this market value of investment fund shares was added. For more details see Czech Republic: Capital Market Review, 1999. 
and ownership structures consolidated, the main indicators of the Czech stock market functioning started to worsen. Moreover, an exceptionally large number of securities were delisted within a relatively short period of time.

\subsection{Delisting process}

PSE authorities attempted to improve market transparency and provide a better arrangement for the trading of hundreds of securities. Market segmentation was introduced in September 1995: the listed market was split into main and secondary markets, and the formerly unlisted securities were transformed into the free market. A large number of unlisted securities did not meet the criteria for the public market (PSE Monthly Report, May 1997), so the PSE authorities decided to delist them, i.e. exclude them from public trading.

Prior to 1997 only an insignificant number of securities were delisted from the PSE. The reasons were mostly bankruptcy and limited transferability of the securities, i.e. the delisting decision was not made by the PSE authorities. In 1997, however, the PSE began to play an active role in the delisting process. The following factors were crucial for the delisting decision: time of registration on the PSE, value of trades on the central market, value and frequency of direct and block trades, market capitalization of the issue, number of trading sessions with a non-zero value of trades on the central market, ownership structure, voluntary disclosure of information on the issuer and the issue and possible interests of the National Property Fund (Monthly Report, May 1997).

Four major waves of massive delisting in 1997 took place on March 20th, April 1st, June 2nd, and October 1st. Altogether 1301 issues were excluded from trading ${ }^{12}$. For each of these delisting waves certain criteria for delisting were set. They are listed in Table 1 below.

Table 1

Delisting Criteria Set by the PSE (the period of the preceding 12 months)

\begin{tabular}{|l|c|c|c|}
\hline CRITERION & $\mathbf{1}^{\text {st }}$ and $\mathbf{2}^{\text {nd }}$ wave & $\mathbf{3}^{\text {rd }}$ wave & $\mathbf{4}^{\text {th }}$ wave \\
\hline $\begin{array}{l}\text { Traded value in the preceding } \\
\mathbf{1 2} \text { months less than }\end{array}$ & USD 6,300 & USD 18,900 & USD 47,300 \\
\hline Market capitalization less than & USD 157,000 & USD 631,000 & \\
\hline $\begin{array}{l}\text { Number of days when security } \\
\text { was traded on the central market }\end{array}$ & less than 5 & less than 80 & less than 200 \\
\hline Delisted issues & $100 ; 391$ & 509 & 301 \\
\hline
\end{tabular}

Source: Prague Stock Exchange, author's calculations (based on the yearly average exchange rate reported by the Czech National Bank)

12 Delisted share issues were afterwards listed on the RM-system (OTC market). Most of the delisted issues were delisted from RM-system as well, the majority later than one year after delisting from PSE. In 2006, only 3\% of the issues delisted from the PSE in 1997 were still traded on the RM-system. 
Figures in this table show that the delisted companies were very small ones that would not be placed on a stock exchange under standard listing conditions. Moreover, they did not even fulfil the official listing requirements at the PSE valid in 1997.13

In 1998 only an insignificant number of securities was delisted, most of them because of the issuer's decision. In 1999, 75 issues were excluded from the free market in order to help increase the transparency of the market. The number of delisted securities continued to decrease in the following years. Table 2 below provides a more comprehensive picture of delisting on the PSE.

Table 2

Reasons for Delisting Firms from the Prague Stock Exchange in 1993-2006

\begin{tabular}{|l|c|c|c|c|c|c|c|c|c|c|c|c|c|c|}
\hline Reason/year & 1993 & $\mathbf{1 9 9 4}$ & $\mathbf{1 9 9 5}$ & $\mathbf{1 9 9 6}$ & $\mathbf{1 9 9 7}$ & $\mathbf{1 9 9 8}$ & $\mathbf{1 9 9 9}$ & $\mathbf{2 0 0 0}$ & $\mathbf{2 0 0 1}$ & $\mathbf{2 0 0 2}$ & $\mathbf{2 0 0 3}$ & $\mathbf{2 0 0 4}$ & $\mathbf{2 0 0 5}$ & $\mathbf{2 0 0 6}$ \\
\hline $\begin{array}{l}\text { Decision of the } \\
\text { authority }\end{array}$ & 0 & 0 & 1 & 11 & 1210 & 1 & 65 & 4 & 13 & 7 & 2 & 0 & 0 & 0 \\
\hline $\begin{array}{l}\text { Decision of the } \\
\text { issuer }\end{array}$ & 6 & 7 & 12 & 37 & 10 & 6 & 11 & 14 & 17 & 5 & 8 & 10 & 16 & 9 \\
\hline $\begin{array}{l}\text { Bankruptcy } \\
\text { related }\end{array}$ & 3 & 3 & 6 & 13 & 5 & 4 & 3 & 10 & 4 & 2 & 0 & 0 & 0 & 0 \\
\hline Total delisted & 9 & 10 & 19 & 61 & 1225 & 11 & 79 & 28 & 34 & 14 & 10 & 10 & 16 & 9 \\
\hline
\end{tabular}

Source: Prague Stock Exchange and author's calculations

Figures in this table confirm that massive delisting took place on the PSE especially in 1997 , when nearly $80 \%$ of all delisted companies left the market. The most important reasons for excluding firms from public trading are based on the decision of the authorities, mostly the PSE. The most common reason is insufficient liquidity of securities (about $80 \%$ of delisted securities). This is followed by the end of public trading based on the decision of the issuer (about $6 \%$ of delisted companies) and more than $4 \%$ of companies were delisted in 1999 when their trading group on the PSE was cancelled. It is thus clear that the official reasons for delisting provided by the responsible authorities are rather broad ${ }^{14}$ and not sufficient to explain the phenomenon of delisting.

Sharp decline in the number of traded shares in conjunction with almost no new companies entering the market hampered the desired development of the newly created market. This leads us to investigate more closely the determinants and the effects of delisting in transition economies. Delisting criteria set by the stock exchange were however only related to trading and market indicators. Our analysis, on the other hand, includes variables describing the state of the company before privatization. We aim to show that survival of companies at the stock exchange was predictable based on

13 Volume of the part of the issue released through public offer had to be at least USD 3.4 mil. and proportion of the issue released through public offer in the total volume of the issue at least $20 \%$. In addition, the issuer had to be in business for at least two years (PSE Monthly Report, February 1997).

14 It is important to note that the time of delisting also plays a role here. The later a certain security was delisted, the more precise the reasons for its delisting. In fact, in 1997, when the highest number of firms was delisted, reasons were not provided for all the delisted companies. 
their situation at the time of entering the market. We examine if and how it might have been possible to prevent delisting and to ensure a more standard development of the emerging stock market. In more general terms, we are interested in determining under what circumstances a viable market for shares arises.

\section{Data and Methodology}

\subsection{Data}

Our data set includes the population of firms privatized in the first and second waves of the mass privatization program. Altogether it contains 1664 medium and large non-financial companies that traded on the Prague Stock Exchange following privatization. Data on privatization come from the Ministry of Privatization of the Czech Republic as well as the Ministry of Finance (privatization projects, pre-privatization data) covering the period 1992-1995. Data on holdings after the first and second privatization waves come from the Prague Securities Centre database. Financial data, together with the post-privatization ownership structure of the companies, are taken from the private database ASPEKT ${ }^{15}$ which is configured using annual reports as well as information provided to the stock exchange and companies' shareholders. Here, the time period of interest are the years 1995-1997, i.e. after privatization but before the major delisting. Finally, the Prague Stock Exchange provided data about delisting for 1993-2006. Details concerning changes in the legal status of delisted companies (bankruptcy, merger, acquisition) were taken from the Czech companies register. ${ }^{16}$ Description of the variables used in the estimation is provided in the appendix (Table A.1).

\subsection{Methodology}

Delisting is modelled as a zero-one phenomenon, i.e. the company is still traded on the stock exchange (0) or it is delisted (1). We estimate a linear probability model where the dependent variable is the probability of delisting. It equals one for companies that were delisted.

The explanatory variables belong to three main groups. Since privatization is critical for identifying the determinants of delisting, we also employ it to help us categorize explanatory variables. The first group thus contains general characteristics of companies prior to privatization i.e. industry, size and financial indicators. The second one relates to the privatization process and its aftermath. Here we account for the wave in which a company was privatized and utilize information from the privatization project prepared by the company managers. We also account for the attractiveness of companies in the privatization process reflected in the average price for which their shares were sold in auctions. If the pre-privatization and privatization

15 ASPEKT database is a Czech source for AMADEUS, a pan-European database containing financial statement data. All financial statements in our data set are audited.

16 www.justice.cz. By further existence we mean existence of the company's capital. Therefore if a company merged with some other company, its capital is still in use and we consider this acceptable for our purposes. 
determinants prove to be significant, we can surmise that the decision to place all the privatized companies on the stock exchange at a time when the stock market was not fully functional and could not bear such a high number of securities was an ill-conceived one. Despite the high expectations of authorities, not all emerging markets are developed enough to deal with this situation. Even in the case of important financial centres the government played an essential role in kick-starting financial development since the laissez-faire approach and secured property rights alone were not sufficient (Andrianova et al., 2008). Finally, the last group of explanatory variables includes company financial indicators after privatization. We do not consider any variables from the stock exchange since their inclusion could cause difficulties in the estimations because of the possible endogeneity problem. ${ }^{17}$ The model that we estimate has the following form:

$$
P\left(y_{i}=1\right)=\alpha+\beta \cdot \text { pre }_{-} \text {priv }_{i}+\gamma \cdot \text { priv }_{i}+\delta \cdot \text { post_priv }{ }_{i}
$$

We also take into account possible connections between variables in different groups. The average share price in a privatization auction reflects the attractiveness of a given company for investors. Thus, if we assume that the market functions well and the future prospects of a company are already included in this price, the post-privatization profit variable could be connected to the average price. This could lead to an endogeneity problem and invalidate our results. To account for this problem, we use the growth in sales and the growth in operational profit instead of plain operational profits and sales as indicators of post-privatization development. ${ }^{18}$ These are defined as the growth rate between the current and the following year of average value in a given industry, excluding the company itself. As the company under consideration is not included in the construction of these indicators, we consider their use appropriate to solve the possible endogeneity problem. Furthermore, these indicators are suitable to describe post-privatization development. Growth in sales reflects the opportunities the company has in its own industry, and the operational profit variable shows the profitability, i.e. resources, available inside the companies. The model we run on the whole data sample has the following specification:

$$
\begin{aligned}
P\left(\text { del }_{i}=1\right)= & \alpha+\beta_{1} \cdot \text { tns }_{i}+\beta_{2} \cdot n p f_{i}+\beta_{3} \cdot \text { prof_tns }_{i}+\gamma_{1} \cdot a p_{i}+\gamma_{2} \cdot a p_{i}{ }^{2}+ \\
& +\gamma_{3} \cdot \text { wave }_{i}+\gamma_{4} \cdot \text { both }_{i}+\delta_{1} \cdot \text { opro_gr }_{i}+\delta_{2} \cdot \text { sales_gr }_{i}+\delta_{3} \cdot \text { mills }_{i}
\end{aligned}
$$

where

- $\quad$ el is a dummy variable that equals 1 for a company that was delisted before the end of 2006 and 0 for not-delisted

- tns is total number of shares of a company (in millions of shares)

17 This problem arises if we assume that the market is functioning properly in a sense that it takes into account the fact that some of the privatized companies should not be listed on the stock exchange. If this assumption holds, the fact that their price or frequency of their trading is low just indicates that the market expects these companies to be delisted and thus the endogeneity problem would be present in the estimations.

18 See Hanousek at al. (2007) for more details on endogeneity issues related to Czech privatized firms as well as its treatment. 
- $\quad n p f$ is the share of a company owned by the National Property Fund, indicated in the company's privatization project

- prof_tns is profit per share one year before privatization

- $\quad a p$ is average price of a company's shares in the privatization auction (in points)

- wave stands for a dummy variable which equals one if the company was privatized in the first privatization wave

- both is a dummy variable that equals one for companies privatized in both waves

- opro_gr is growth in operational profit defined as the growth rate of average operational profit in the industry (between 1996 and 1997), excluding the company itself

- sales_gr stands for growth opportunities, defined as the growth rate of average sales in the industry (between 1996 and 1997), excluding the company itself

- mills is the inverse Mills ratio ${ }^{19}$

The inverse Mills ratio enables us to account for the missing financial data problem. Even though our sample contains all the companies privatized under the voucher privatization scheme, we face the problem of missing observations, due to the fact that not all the companies were willing to report their financial results. This refusal was possible because market supervision as well as law enforcement after privatization were weak. The presence of missing observations leads to a sample selection bias problem that we address by employing a two-stage estimation (Heckman, 1979). The main part of this estimation constitutes the linear probability model described above. In order to obtain the inverse Mills ratio for this model we examine the firms that do not report information about their profits before and after privatization and consider the factors determining their decision. This approach is a Heckit regression where we employ probit estimation in the first stage and a linear probability model in the second. We have chosen a linear probability model for several reasons. Firstly, it allows us to instrument for profit and, in comparison to logit, it provides consistent estimates under standard assumptions (Angrist and Krueger, 2001). Moreover, the linear probability model can be corrected for sample selection.

The probit regression, with the dependent variable being missing financial data as a binary response, that we estimate first has the following form:

$$
P\left(\text { sel }_{i}=1\right)=\text { const }+\alpha \cdot \text { size }_{i}+\beta \cdot \text { owner }_{i}+\gamma \cdot \text { ipf }_{i}+\delta \cdot \text { ind }_{i}+\omega \cdot \text { miss }_{i}
$$

where size accounts for the size of the company ${ }^{20}$ and its proportion privatized in the voucher privatization. The set of variables concerning the ownership structure (owner) described in the privatization project includes dummy variables for domestic and foreign owners as well as restitutions, National Property Fund share, municipalities, and selling via intermediaries. IPF stands for the actual ownership shares owned by the investment privatization funds following the privatization. We further account for

19 It is the ratio of the probability density function for the standard normal over its cumulative density function.

20 We also add a quadratic term to this variable, since we expect the relationship to be non-linear. 
the industry to which a given company belongs (ind) ${ }^{21}$ Moreover, we define a dummy variable based on the firm's reporting or non-reporting in the pre-privatization period (miss). If a company has not reported some of its financial indicators previously, ${ }^{22}$ we assume that there is a high probability that it will continue doing so also after privatization.

Besides this basic two-stage model where we only distinguish between delisted and not-delisted share issues, we also employ a more precise classification of companies based on the three main reasons for delisting: decision of the authority, decision of the issuer, and bankruptcy-related reasons. The determinants of delisting may be different for each of these subgroups. The results of our preliminary investigation confirm that the proportions of missing observations are not significantly different when accounting for different delisting reasons ${ }^{23}$ and therefore there is no need to estimate the model in two stages as there was for the one above, where we only distinguished between delisted and not-delisted companies. Rather, we run a multinomial logit estimation based on a similar model specification as before (Equation 2), where the dependent variable takes four different values. These values represent not-delisted firms, firms delisted under authoritative decision, issuer, and bankruptcy, respectively.

\section{Estimation and Results}

In order to estimate the influence of different factors on delisting we run the above described two-stage Heckit regression on the sample including all companies ever listed on the PSE. The linear probability model (Equation 2) provides us with the results summarized in Table 3.

All the explanatory variables included in the model with the exception of the pre-privatization profit indicator are significant. The estimated effects exhibit the expected signs. There are two possible explanations for the non-significance of the pre-privatization profit. The first has to do with the quality of the data from the pre-privatization period. The indicator of profit in this case does not reflect profit but production, and therefore does not necessarily provide a true picture of the situation in a given company; as evidenced also by Hanousek at al. (2009). The other explanation is the possibility of tunnelling.

The significance of other factors indicates that delisted companies exhibited, before and during the actual privatization, different characteristics from companies that remained on the stock exchange. Especially the size of the company (measured by the total number of shares which corresponds to the company's book value) and the ownership structure described in the privatization project have played a role here. These results confirm our expectations that larger companies have a lower probability of being delisted. A one standard deviation change in the size of a company measured by total number of shares decreases the probability of delisting by 4 percent (the last column in Table 3). This result indicates that an increase in the size of a company by

21 We use PSE classification.

22 At least two out of the three pre-privatization indicators are missing in our sample.

23 Data on proportions of missing observations in subgroups of companies delisted for different reasons are available upon request. 
a million shares decreases the probability of delisting by 2.26 percent. The significance and magnitude of the results also indicate that, as we have argued earlier, not all companies privatized in mass privatization were suitable candidates for immediate placement on the stock exchange. Size of the company could have been used as a filter so as to prevent the emergence of a non-transparent market.

Table 3

Linear Probability Model for Delisting ( $y=1$ for delisting)

\begin{tabular}{|l|c|c|c|}
\hline & \multicolumn{2}{|c|}{ Linear probability model } & Interpretation \\
\hline Pre-privatization factors & $\begin{array}{c}\text { Estimated } \\
\text { coefficient }\end{array}$ & Standard Error & $\begin{array}{c}\text { Overall } \\
\text { effect (one } \\
\text { st. deviation } \\
\text { change) }\end{array}$ \\
\hline $\begin{array}{l}\text { Total number of shares (millions of } \\
\text { shares) }\end{array}$ & $-0.0226^{* *}$ & 0.010 & $-4 \%$ \\
\hline $\begin{array}{l}\text { Profit before privatization (scaled by } \\
\text { book value) }\end{array}$ & $6.5 \mathrm{E}-06^{*}$ & 0.0003 & $0.01 \%$ \\
\hline Privatization factors & $\begin{array}{c}\text { Estimated } \\
\text { coefficient }\end{array}$ & Standard Error & \\
\hline National property fund ownership & $-0.003^{* * *}$ & 0.001 & $-4.26 \%$ \\
\hline $\begin{array}{l}\text { Average price in voucher auction } \\
\text { (in points) }\end{array}$ & $-0.001^{* * *}$ & 0.0003 & $-5.66 \%$ \\
\hline Average price (squared) & $1.1 \mathrm{E}-06^{* * *}$ & $2.5 \mathrm{E}-07$ & $0.31 \%$ \\
\hline Average price (overall effect) & & & $-5.35 \%$ \\
\hline Privatization wave & $-0.055^{* * *}$ & 0.015 & \\
\hline Privatized in both waves & $-0.057^{* *}$ & 0.028 & \\
\hline Post-privatization factors & $\begin{array}{c}\text { Estimated } \\
\text { coefficient }\end{array}$ & Standard Error & \\
\hline Operational profit growth & $-0.0001^{* * * *}$ & $3.9 \mathrm{E}-05$ & $-2.65 \%$ \\
\hline Growth opportunities (sales) & $0.006^{* * *}$ & 0.001 & $4.31 \%$ \\
\hline Mills ratio (sample selection) & $0.353^{* * *}$ & 0.087 & \\
\hline Constant & $0.885^{* * *}$ & 0.027 & \\
\hline Number of observations & & 1,470 & \\
\hline Adjusted R $^{* *}$ & & & \\
\hline
\end{tabular}

Note: The table contains estimation results for the linear probability model. We report estimated coefficients as well as their significance $\left({ }^{*}\right.$ significant at $10 \%,{ }^{* *}$ significant at $5 \%$ and ${ }^{* * *}$ significant at $1 \%$ ). In the linear probability model the estimated coefficients correspond to the marginal effect.

In addition to company size, the proportion of shares held by the National Property Fund (NPF) could serve as a predictor of possible delisting. Our results show that an increase in the number of shares owned by the NPF by one percent decreases the probability of delisting by 0.3 percent, which is in the one standard deviation change measure as much as 4.3 percent. This is because the state tends to play a special role in the ownership structure and, in this case, also indicates the future intentions of the 
state towards the privatized company. ${ }^{24}$ Another important privatization factor is the average price of the privatized companies' shares. As we expect to find a non-linear relationship between average price and delisting, average price is also included in quadratic form. A higher price indicates a higher valuation of the company by bidders ${ }^{25}$ and thus greater expected future prospects and lower probability of being delisted. The results of our estimation support this hypothesis. A one standard deviation increase in price decreases the probability of delisting by 5.35 percent. Thus, the average price in the voucher auction is shown to be one of the most important predictors of delisting.

Another decisive factor is the wave in which a given company was privatized. Our results suggest that the probability of delisting companies privatized in the first privatization wave is 5.5 percent lower than for other companies. This result is in line with the findings of Gupta et al. (2000), who provide evidence that in the Czech Republic more profitable firms were privatized first.

Massive delisting took place in 1997, and thus post-privatization company characteristics are expected to influence delisting. We consider operational profit which is, in comparison to pre-privatization profit, based on standard accounting practices and, unlike the overall profit variable, better reflects the real functioning of a given company because it does not include extraordinary items. The years under consideration are 1996 and 1997; this time period directly follows privatization and at the same time precedes the main waves of delisting. Due to a possible connection between profit and the average price in the privatization auction we construct an operational profit growth variable based on the operational profit growth in a given industry. Its estimated coefficient is significant and its sign indicates that a decrease in growth of operational profits by one percentage point increases the probability of delisting by 0.01 percent, which in the standard deviation change measure translates into 2.65 percent. This result corresponds to our expectations, even though the effect is not as strong as in the case of pre-privatization and privatization factors, which play a key role in explaining delisting.

The estimated model also considers future prospects of a listed company. We include a forward-looking indicator that accounts for a company's growth opportunities. As described in the methodology section, it is based on the growth of sales in a given industry. Similar to our expectations, the estimated coefficient is significant. One would expect it to have a negative sign, so that the probability of delisting would decrease with higher growth opportunities. It is, however, positive, and a one standard deviation increase in growth opportunities constitutes a 4.3 percent increase in the probability of delisting. This means that future prospects play a role in delisting, but also suggests that the new owners can, despite a promising future, exercise their power and tunnel the company.

24 Most of the companies where the state owned a significant proportion of shares were so called strategic companies, see Hanousek and Kočenda (2008) for detailed exposition.

25 Hanousek and Filer (2001) show that the prices of larger firms comprising the bulk of assets in the mass privatization scheme rapidly incorporated all the public as well as private information. Further, Hanousek and Kočenda (2010) showed that bidders consistently accounted for price adjustment in their bidding behaviour. 
The inverse Mills ratio is significant, which indicates that an unwillingness to report financial results plays a role in the delisting process and that the two-stage estimation procedure is necessary. $\mathrm{R}^{2}$ as a measure for goodness of fit is not very high, however; taking into account the structure of the model and a relatively high number of delisted companies, we cannot expect it to be much higher. ${ }^{26}$ Thus, the estimated model is significant and supports our hypothesis: there exist several economic measures, especially from the pre-privatization and privatization period, which could have predicted the delisting of certain companies and which could have been used to decide which companies to place on the stock exchange for public trading after mass privatization.

\subsection{Reasons for delisting}

Besides distinguishing between delisted and not-delisted companies, we also examine reasons for delisting. We identify three main categories of reasons based on information from the PSE: decision of the authority, decision of the issuer, and bankruptcy-related. We deem it important to examine the determinants of delisting for these categories and employ a multinomial logit model to do it. It has the form of the basic model (Equation 2) without Mills ratio, but the dependent variable is different in this case. It can take four different values:

- 0 for companies that were not delisted

- 1 for companies delisted based on the decision of the authority

- 2 for companies delisted at the issuer's request

- 3 for bankruptcy-related delisting

The estimation results uncover differences between groups of companies delisted for different reasons. As Table 4 shows, the most significant results are obtained for the subgroup delisted due to the decision of the authority. This result is most probably also due to the size of this subgroup, as it contains as many as 1200 observations (which comprise $82 \%$ of the whole sample). The results for companies delisted due to authoritative decision are in line with the results obtained for the basic model. The marginal effects that are reported stress the importance of company size, which is the most influential determinant of delisting because the probability of delisting decreases by $30 \%$ when increasing the number of shares by one million. Nevertheless, unlike the basic model, the coefficient for the NPF variable is insignificant here. This may indicate that the significance of the NPF variable in the basic model was primarily driven by the companies that were not delisted. However, now when we distinguish subgroups of companies in more detail, the effects across them differ and the NPF variable becomes significant even for smaller subgroups.

26 Nevertheless, our model dominates naive estimators on the basis of their predictive accuracy. These results are available upon request. 
Table 4

Multinomial Logit Model Based on Different Reasons for Delisting

\begin{tabular}{|c|c|c|c|c|c|c|}
\hline \multirow{2}{*}{$\begin{array}{l}\text { MULTINOMIAL LOGIT } \\
\text { Pre-privatization factors }\end{array}$} & \multicolumn{2}{|c|}{$\begin{array}{l}\text { Decision of the } \\
\text { authority }\end{array}$} & \multicolumn{2}{|c|}{ Decision of the issuer } & \multicolumn{2}{|c|}{ Bankruptcy related } \\
\hline & coefficient & $d P / d X$ & coefficient & $\mathrm{dP} / \mathrm{dX}$ & coefficient & $d P / d X$ \\
\hline $\begin{array}{l}\text { Total number of shares } \\
\text { (millions) }\end{array}$ & $-2.345^{* * *}$ & -0.296 & 0.003 & 0.127 & 0.046 & 0.05 \\
\hline $\begin{array}{l}\text { Profit before privatization } \\
\text { (scaled by book value) }\end{array}$ & -0.0031 & 0.001 & -0.034 & -0.002 & -0.0005 & 0.0002 \\
\hline \multicolumn{7}{|l|}{ Privatization factors } \\
\hline NPF ownership & -0.003 & 0.002 & $-0.035^{* * *}$ & -0.002 & $-0.022^{*}$ & -0.0004 \\
\hline Average price (in points) & $-0.016^{* * *}$ & -0.002 & 0.003 & 0.001 & -0.007 & 0.0001 \\
\hline Average price (squared) & $2.8 \mathrm{E}-05^{* *}$ & $5.9 \mathrm{E}-07$ & $-1.2 \mathrm{E}-05$ & $-2.0 \mathrm{E}-06$ & -0.0001 & $-3.0 \mathrm{E}-06$ \\
\hline Average price (together) & & -0.002 & & 0.001 & & -0.0003 \\
\hline Privatization wave & $-1.081^{* * *}$ & -0.13 & -0.118 & 0.049 & 0.111 & 0.026 \\
\hline Privatized in both waves & $-0.695^{\star *}$ & -0.082 & -0.325 & 0.012 & 0.584 & 0.033 \\
\hline \multicolumn{7}{|l|}{ Post-privatization factors } \\
\hline $\begin{array}{l}\text { Growth opportunities } \\
\text { (sales) }\end{array}$ & $0.053^{* * *}$ & 0.004 & 0.030 & -0.001 & $0.0471^{*}$ & 0.0002 \\
\hline Operational profit growth & $-0.001^{* *}$ & -0.0001 & -0.0003 & 0.0001 & $-0.002^{* *}$ & $-3.2 \mathrm{E}-05$ \\
\hline Constant & $3.758^{* * *}$ & 0.491 & 0.041 & -0.196 & $-1.051^{*}$ & -0.11 \\
\hline Number of observations & \multicolumn{6}{|c|}{1,656} \\
\hline Scaled $\mathrm{R}^{2}$ & \multicolumn{6}{|c|}{0.245} \\
\hline
\end{tabular}

Note: The table contains estimation results for the multinomial logit model where reasons for delisting are taken into account. The results for not-delisted companies are not reported (it is possible to count them based on these numbers as the sum of probabilities equals 1 ). We report estimated coefficients, their significance $\left({ }^{*}\right.$ significant at $10 \%$, ** significant at $5 \%$ and ${ }^{* * *}$ significant at $\left.1 \%\right)$ as well as marginal effects (dP/dX) for the particular reasons for delisting. Marginal effects are calculated as partial derivatives of the response probability function with respect to explanatory variable under consideration.

Yet, the effect of a lower number of observations is visible on the significance of the other coefficients for companies delisted in the two other subgroups. When interpreting these results a further clarification is necessary. Companies delisted based on the issuer's request can be of two types. The first is represented by companies that are, due to their size or area in which they operate, not appropriate candidates for public trading and whose owners decided to delist in order to overturn the administrative decision to list them that followed mass privatization. On the other hand, there are companies whose owners opted to delist because they did not wish to disclose information about the company to the public. These two explanations split this subgroup, which already contains a relatively low number of observations, even more and hence it is not possible to expect any significant results. In spite of this, the ownership share of the NPF plays a significantly negative role in the decision of the issuer subgroup. This result only confirms that companies where NPF has an ownership share are not expected to be delisted, especially if the reason for delisting is 
the decision of the issuer. The strong position of the NPF is also visible in the subgroup delisted due to bankruptcy, where the NPF ownership variable is significant as well but its effect is much smaller. The most important variable for the bankruptcy-related subgroup is the operational profit growth variable. This is exactly what one would expect, as operational profit is a crucial indicator of a company's functioning. Even though its effect is significant, it is not very high. Thus, despite the fact that not all the results in this specification are significant, there are visible trends that confirm differences between companies delisted for different reasons that are in line with our expectations and previous estimations.

\subsection{Robustness check}

Identifying the reasons for delisting based on the information we have available is rather difficult and there are several ways to view the evidence. In the estimations conducted above we mostly considered the reasons provided by the stock exchange. The most common reason for delisting given by the stock exchange was insufficient liquidity. In the main estimations by reasons we have treated this as a decision of the authority. In the alternative classification we consider companies delisted because of insufficient liquidity to be part of the group delisted due to the decision of the issuer. This is because insufficient liquidity indicates the presence of a dominant owner who, if he does not want his company to be publicly traded, in fact need not do anything. Since the free float of company's shares is generally low, he only waits until the company is delisted because of insufficient liquidity. This raises questions about delisting de facto and de jure. Delisting de jure is the official delisting reported by the stock exchange, while delisting de facto concerns the real behaviour of the issuers. If taking delisting as de facto, then delisting due to insufficient liquidity can be considered a decision of the issuer. As part of a sensitivity analysis, we consider an alternative division of companies based on de facto delisting and run the multinomial logit model described above on the new subgroups. The estimation results correspond to the ones reported in Table 4. The most significant results are obtained for the subgroup with the highest number of observations, and the signs and magnitudes of the estimated coefficients are in line with the results of our basic model. The results for the subgroup of companies delisted due to bankruptcy, which stays the same as in the original division, remain basically unchanged. All of this thus reconfirms our previous results.

Furthermore, our main estimations have also been carried out on the subsample that includes companies delisted in the four major waves in 1997 and those that have survived 1997. The companies in this subsample are the most important from the point of view of delisting, as delisting was relatively rare and insignificant before 1997. The estimations on this subsample show the same pattern of results as were described for all the companies. In this way we have in fact used this subsample to check the robustness of our results.

We also include industrial dummy variables in the linear probability model estimated as the second stage of the Heckit regression. The industrial dummies were defined rather broadly and we only distinguished between heavy and light industries. Even when including these dummies, the estimated coefficients of other explanatory variables remained basically unchanged; this result confirms the robustness of our findings. 


\section{Conclusion}

In its short history the Czech stock market, unlike the Polish or Hungarian one, experienced massive delisting of shares and virtually no initial public offerings. Such delisting was due to the fact that all privatized companies were simply placed on the market by administrative directive following mass privatization. Interestingly, in addition to the Czech Republic, massive delisting was also observed in other transition countries ${ }^{27}$ where the initial conditions were similar, i.e. mass privatization. Massive delisting in conjunction with almost no new companies entering the market put off the development of these markets.

In this paper we investigate the determinants of delisting and claim that it was possible to prevent massive delisting. The results of our estimation indicate that there exist several factors based on which it was possible to identify companies that were going to be delisted even before the actual delisting took place. Most of these determinants of delisting are connected to the pre-privatization and privatization period. This indicates that it could have been possible to prevent delisting if these factors had been taken into account when deciding which companies to place on the stock exchange for public trading following mass privatization. In light of the overall development of the PSE, we conjecture that massive delisting not only served to correct the poor decision of the privatization authorities by cleaning the market of unsuitable shares, but also sent a signal concerning the functioning of the whole market. Cleaning had a positive effect in the long run because the market became more transparent. Nevertheless, in the short run delisting seems to have had a negative effect on price development and on the size of the market.

This development suggests that government decisions concerning privatization programs which influence emerging stock markets should be made very carefully, especially when choosing which companies to privatize using a particular method and choosing the criteria based on which these companies will be placed on the stock exchange. If a proper means of filtering companies had been implemented in the Czech Republic before placing privatized companies on the stock exchange, a more transparent stock market which could fulfil its main economic functions would have emerged after the privatization.

\section{References}

Andrianova, S., Demetriades, P., Xu, Ch. (2008), "Political Economy Origins of Financial Markets in Europe and Asia." Discussion Papers in Economics 08/1, Department of Economics, University of Leicester.

Angrist, J. D., Krueger, A. B. (2001), "Instrumental Variables and the Search for Identification: From Supply and Demand to Natural Experiments." Journal of Economic Perspectives 15(4): pp. 69-85.

Atanasov, V., Black, B., Ciccotello, C. S., Gyoshev, S. B. (2010), "How Does Law Affect Finance? An Examination of Equity Tunneling in Bulgaria." Journal of Financial Economics 96(1): pp.155-173.

Bakker, M., Gross, A. (2004), "Development of Non-bank Financial Institutions and Capital Markets in European Union Accession Countries." World Bank Working Paper No. 28.

27 Even though the developments in transition countries differed, besides the Czech Republic delisting took place in Bulgaria, Lithuania, and Slovakia. 
Bonin, J., Wachtel, P. (2003), "Financial Sector Development in Transition Economies: Lessons from the First Decade." Financial Markets, Institutions and Instruments, 12(1): pp. 1-66.

EBRD (European Bank for Reconstruction and Development) (1995-2003), Transition Report, various issues.

Gupta, N., Ham, J., Švejnar, J. (2000), "Priorities and Sequencing in Privatization: Theory and Evidence from the Czech Republic." William Davidson Institute Working Paper No. 323.

Egert, B., Kočenda, E. (2007), "Interdependence between Eastern and Western European Stock Markets: Evidence from Intraday Data." Economic Systems, 31(2), pp. 184-203.

Fungáčová, Z., Hanousek, J. (2006), "A Castle Built on Sand: The Effects of Mass Privatization on Stock Market Creation in Transition Economies." Bank of Finland Institute for Economies in Transition Discussion Paper 14/2006.

Hanousek, J., Filer, R. (2000), "The Relationship between Economic Factors and Equity Markets in Central Europe." Economics of Transition 8(3): pp. 623-638.

Hanousek, J., Filer, R. (2001), "Informational Content of Prices Set Using Excess Demand: The Natural Experiment of Czech Voucher Privatization." European Economic Review 45: pp. 1619-1646.

Hanousek, J., Kočenda, E. (2010), "Learning by Investing: Evidence from a Naturally-Occurring Auction." Forthcoming in Economics of Transition.

Estrin, S., Hanousek, J., Kočenda, E., Švejnar, J. (2009), "Effects of Privatization and Ownership in Transition Economies." Journal of Economic Literature, 47(3), pp, 699-728.

Hanousek, J., Kočenda, E. (2008), "Potential of the State to Control Privatized Firms." Economic Change and Restructuring, 41(2), pp. 167-186.

Hanousek, J., Kočenda, E., Švejnar, J. (2007), "Origin and Concentration: Corporate Ownership, Control and Performance in Firms after Privatization." Economics of Transition, 15(1), pp. 1-31.

Hanousek, J., Kočenda, E., Švejnar, J. (2009), “Divestitures, Privatization and Corporate Performance in Emerging Markets." Economics of Transition, 17(1), pp. 43-73.

Hanousek, J., Podpiera, R. (2004), "Czech Experience with Market Maker Trading System." Economic Systems 28: pp. 177-191.

Heckman, J. (1979), "Sample Selection Bias as a Specification Error." Econometrica 47, pp. 153-161.

Kočenda, E., Valachy, J. (2002), “Firm Ownership Structures: Dynamic Development." Prague Economic Papers, 11(3), pp. 255-268.

Kotrba, J. (1995), "Privatization Process in the Czech Republic: Players and Winners," in Švejnar J.: The Czech Republic and Economic Transformation in Eastern Europe, San Diego, London and Toronto: Harcourt Brace, Academic Press, pp. 159-198.

Köke, J., Schröder, M. (2002), "The Prospects of Capital Markets in Central and Eastern Europe," ZEW Discussion Paper No. 02-57.

Lieberman, I. W. (1997), "Mass Privatization in Comparative Perspective," in Lieberman I., Stilpon N., Raj D. (Eds.): Between State and Market: Mass Privatization in Transition Economies, The World Bank and OECD.

Mašek, F. (2005), "Ani rekordy vše neřeší (Records will not solve all the problems)." Ekonom 3/2005.

Pop, D. (2006), "M\&A Market in Transition Economies: Evidence from Romania." Emerging Markets Review 7, pp. 244-260.

Prague Stock Exchange (1993-2005), Annual and Monthly Reports, various issues.

Simoneti, M. (1997), "Regulating Post-privatization Securities Markets in Transition Economies," in Lieberman I., Stilpon N., Raj D. (Eds.), Between State and Market: Mass Privatization in Transition Economies, The World Bank and OECD.

The Economist (1991), "Giving Companies away is Better than Keeping them in State Hands." September 21, A18-A20.

World Bank (1999), Czech Republic: Capital Market Review. The World Bank Washington, D.C. 


\section{Appendix}

Table A.1

Definitions and Data Sources of the Variables Included in the Analysis

\begin{tabular}{|c|c|c|}
\hline VARIABLE NAME & SOURCE & DESCRIPTION \\
\hline Industry (ind_id_burza) & PSE classification & $\begin{array}{l}\text { the code of industry at the PSE: it includes } 19 \\
\text { categories out of which } 17 \text { are relevant for us }\end{array}$ \\
\hline Employees (e3, e2, e1) & $\begin{array}{l}\text { Ministry of Privatization } \\
\text { of the Czech Republic }\end{array}$ & $\begin{array}{l}\text { number of employees in the company before } \\
\text { privatization }\end{array}$ \\
\hline $\begin{array}{l}\text { Total number of shares } \\
\text { (tns) }\end{array}$ & $\begin{array}{l}\text { Ministry of Privatization } \\
\text { of the Czech Rep. (MP } \\
\text { CR) }\end{array}$ & $\begin{array}{l}\text { the total number of shares of a firm i.e. capital of } \\
\text { a firm divided by the value of one share }(1000)\end{array}$ \\
\hline Sales $(\mathrm{s} 3, \mathrm{~s} 2, \mathrm{~s} 1)^{*}$ & MP CR & $\begin{array}{l}\text { sales prior to privatization (three, two and one } \\
\text { year) }\end{array}$ \\
\hline Profit $(p 3, p 2, p 1)^{*}$ & MP CR & $\begin{array}{l}\text { profit prior to privatization (three, two and one } \\
\text { year) }\end{array}$ \\
\hline Debt $(\mathrm{d} 3, \mathrm{~d} 2, \mathrm{~d} 1)^{*}$ & MP CR & debt prior to privatization (three, two and one year) \\
\hline Privatization wave (cvl) & MP CR & $\begin{array}{l}\text { the wave in which a certain company was } \\
\text { privatized } \\
\text { (first or second); we also distinguish companies } \\
\text { that were privatized in both waves }\end{array}$ \\
\hline $\begin{array}{l}\text { National Property Fund } \\
\text { ownership share (npf) }\end{array}$ & MP CR & $\begin{array}{l}\text { proportion of a company's shares that based on } \\
\text { the privatization project were supposed to be } \\
\text { owned by the National Property Fund }\end{array}$ \\
\hline Average price (ap) & MP CR & $\begin{array}{l}\text { average price of the firm's shares sold in the } \\
\text { voucher auctions; sold points divided by shares } \\
\text { sold }\end{array}$ \\
\hline $\begin{array}{l}\text { Number of shares in } \\
\text { voucher } \\
\text { privatization (nscp_tns) }\end{array}$ & MP CR & $\begin{array}{l}\text { the number of shares offered in the voucher } \\
\text { privatization as } \% \text { of total number of shares }\end{array}$ \\
\hline $\begin{array}{l}\text { IPFs' holdings after } \\
\text { the first wave (ipf1_tns) }\end{array}$ & $\begin{array}{l}\text { Prague Securities } \\
\text { Centre }\end{array}$ & $\begin{array}{l}\text { shares held by the investment privatization funds } \\
\text { following the } 1 \text { st privatization wave ( } \% \text { of total } \\
\text { number of shares) }\end{array}$ \\
\hline $\begin{array}{l}\text { IPFs' holdings after } \\
\text { the second wave } \\
\text { (ipf2_tns) }\end{array}$ & $\begin{array}{l}\text { Prague Securities } \\
\text { Centre }\end{array}$ & $\begin{array}{l}\text { shares held by the investment privatization funds } \\
\text { following the second privatization wave (\% of total } \\
\text { number of shares) }\end{array}$ \\
\hline Single largest owner (slo) & $\begin{array}{l}\text { Prague Securities } \\
\text { Centre }\end{array}$ & $\%$ of shares held by the single largest owner \\
\hline Profit (1996-2003) & ASPEKT database & profit defined by Czech accounting standards \\
\hline Oper. profit (1996-2003) & ASPEKT database & $\begin{array}{l}\text { operational profit defined by Czech accounting } \\
\text { standards }\end{array}$ \\
\hline Sales (1996-2003) & ASPEKT database & sales defined by Czech accounting standards \\
\hline Total assets (1996-2003) & ASPEKT database & $\begin{array}{l}\text { total assets defined by Czech accounting } \\
\text { standards }\end{array}$ \\
\hline $\begin{array}{l}\text { Total liabilities (1996- } \\
\text { 2003) }\end{array}$ & ASPEKT database & $\begin{array}{l}\text { total liabilities defined by Czech accounting } \\
\text { standards }\end{array}$ \\
\hline
\end{tabular}

Note: The data marked with * are based on socialist accounting 